\title{
ULTRASTRUCTURAL MORPHOMETRY OF NEUROSECRETORY GRANULES IN THE NEUROBLASTOMAS OF PAEDIATRIC PATIENTS
}

\section{ULTRASTRUKTURNA MORFOMETRIJA NEUROSEKRETORNIH GRANULA NEUROBLASTOMA PEDIJATRIJSKIH BOLESNIKA}

\author{
Sofija Jovanović ${ }^{1}$ Tamara Kravić-Stevović
}

${ }^{1}$ University of Belgrade, Faculty of Medicine, Belgrade, Serbia

${ }^{2}$ University of Belgrade, Faculty of Medicine, Institute of Histology and Embryology, Belgrade, Serbia

Correspondence: jovanovicdsofija@gmail.com

Keywords:

neurosecretory granules, peripheral neuroblastic tumours, prognosis, ultrastructural morphometry
Abstract

Introduction: Peripheral neuroblastic tumours are among the most frequently detected tumours in paediatric patients. A correlation between the aggressiveness of these tumours and their clinical prognosis has been discovered. Neurosecretory granules containing neurotransmitters, an ultrastructural feature of neurons, were found in the cells of peripheral neuroblastic tumours, as well.

Aim: The aim of this study was to compare the number of neurosecretory granules found in cells of tumours, with a favourable prognosis to the corresponding number in cells of tumours and with an unfavourable one with the use of transmission electron microscopy (TEM).

Material and Methods: Ten tissue biopsies were obtained from paediatric patients diagnosed with peripheral neuroblastic tumours. The tumour samples were first frozen, then fixed in glutaraldehyde, and embedded in epoxy resin. Ultrastructural morphometric analysis was performed on ultrathin sections.

Results: When observed under a transmission electron microscope (TEM), neurosecretory granules appear as round structures of a small diameter, with an electron dense centre surrounded by an electron lucent, peripheral halo. It was found that the cells of tumours with an unfavourable prognosis have more neurosecretory granules (141.2 \pm 89.18 per 60 cells per sample, on average) in their cytoplasm than the cells of tumours with a favourable one (37.2 \pm 41.17 per 60 cells per sample, on average).

Conclusion: The larger number of neurosecretory granules found in cells of tumours with an unfavourable prognosis could potentially shed some light on the role these structures play in tumourigenesis of peripheral neuroblastic tumours.
Jovanović S. et al. MedPodml 2018, 69(1):60-64 (C)

The authors declare no conflicts of interest. doi:10.5937/mp69-13874

Editorial board: podmladak.med.bg@gmail.com 
Jovanović S. et al. Ultrastructural morphometry of neurosecretory granules in the neuroblastomas of paediatric patients. MedPodml

\section{Sažetak}

Uvod: Periferni neuroblastni tumori jedni su od najčešćih ekstrakranijalnih pedijatrijskih tumora. Primećeno je da morfološke karakteristike ovih tumora koreliraju sa njihovom agresivnošću i kliničkom prognozom. Neurosekretorne granule (NSG) sa neurotransmiterima, koje su normalno prisutne u neuronima, mogu se naći i u ćelijama perifernih neuroblastnih tumora.

Cilj: Cilj ovog rada je da se pomoću transmisionog elektronskog mikroskopa uporedi broj neurosekretornih granula u ćelijama tumora sa dobrom u odnosu na ćelije tumora sa lošom prognozom.

Materijal i metode: Biopsije tumorskih tkiva dobijene su od 10 novodijagnostikovanih pedijatrijskih bolesnika sa perifernim neuroblastnim tumorima. Uzorci tumora su prvo zaleđeni, potom fiksirani u glutaraldehidu, pa kalupljeni u epoksi smolama. Ultrastrukturna morfometrijska analiza vršena je na ultratankim isečcima.

Rezultati: Posmatrane transmisionim elektronskim mikroskopom, NSG se u citoplazmi tumorskih ćelija vide kao okrugle strukture malog prečnika sa elektronski gustim

Ključne reči:

neurosekretorne granule, periferni neuroblastni tumori,

prognoza, ultrastrukturna morfometrija centrom i elektronski svetlim haloom. U ćelijama tumora s lošom prognozom utvrđeno je prisustvo većeg broja (prosečan broj po uzorku na 60 ćelija bio je $141,2 \pm 89,18$ ) neurosekretornih granula u poređenju sa ćelijma tumora s boljom prognozom (prosečan broj po uzorku na 60 ćelija bio je 37,2 $\pm 41,17$ ).

Zaključak: Povećanje broja neurosekretornih granula u ćelijama tumora s lošom prognozom moglo bi delimično da rasvetli ulogu ovih struktura u genezi perifernih neuroblastnih tumora.

\section{Introduction}

Peripheral neuroblastic tumors (pNTs) are defined as embryonic neoplasias of the sympathetic nervous system, that originate from primordial neural crest cells, and are found in the adrenal medulla and sympathetic ganglia, be it the paravertebral ganglions or the paraganglions (e.g. the organ of Zuckerkandl) (1). Carcinogenesis initiates in the fetal or early neonatal period, disabling further differentiation of cells of the future adrenal medulla, autonomic nervous system, Schwann cells, melanocytes and some members of the diffuse neuroendocrine system (DNES) (2). These tumours represent a type of the most frequently diagnosed solid, extracranial growths of early childhood and additionally stand out by the heterogeneous wide scope of clinical symptoms their diagnosis entails (1). They are responsible for $15 \%$ of all solid tumours observed in patients aged four years or younger, central nervous system tumours excluded $(1,3)$.

According to the International Neuroblastoma Pathology Classification (INPC), there are four categories of peripheral neuroblastic tumors, depending on their histopathological characteristics. Those are the following: neuroblastomas $(\mathrm{NB})$, intermixed type ganglioneuroblastomas (iGNB), ganglioneuromas (GN) and nodular type ganglioneuroblastomas (nGNB) (4). More commonly in use, however, is the categorization that delineates tumours with a favorable histology and prognosis (FH), GNs and iGNBs, as opposed to those with an unfavorable histology and prognosis (UH), NBs and nGNBs, respectfully (5).

In cells of peripheral neuroblastic tumours, there are neurosecretory granules (NSG), same in nature as those observed in neuronal processes (6). In neurons these granules are created in the perikaryon, more specifically in the Golgi zone, and transported in an anterograde manner, through the cytoplasm, via microtubules down the length of the axon, and the terminal buttons of axons, where they detach from the cisternae of the endoplasmic reticulum (7). Neurotransmitters are released from the NSGs by way of exocytosis (8).

Transmission electron microscopy (TEM) shows NSGs to be round structures with an electron dense, centrally pinned core and a lighter, periphery bound halo (7). The (co)transmitter molecules are normally situated in the granules' centre (9).

The aim of this study was to compare the number of neurosecretory granules found in cells of tumours with a favourable prognosis to the corresponding number counted in the cells of tumours with an unfavourable one.

\section{Materials and Methods}

\section{Patient samples}

To the purpose of this study, authors analysed samples acquired through biopsies of peripheral neuroblastic tumour tissue from ten newly diagnosed, previously untreated paediatric patients (ranging in age between 3 months and 15 years and 11 months, with an average age of 48.7 months at the time of diagnosis) at the "Institute for health protection of mother and child of Serbia - Vukan Čupić". Six of the patients were male, whereas the remaining four were female. The patients' identities were not disclosed before, during or after the survey.

Aforementioned samples were kept at $-80^{\circ} \mathrm{C}$, up until the point of their processing for electron microscopy. Having taken into consideration the tumours' prognosis, the ten specimens were divided into two main subgroups: 
Jovanović S. et al. Ultrastructural morphometry of neurosecretory granules in the neuroblastomas of paediatric patients. MedPodml 2018, 69(1):60-64

five samples came from FH tumours (GNB, iGN), whereas the remaining five came from $\mathrm{UH}$ tumours (NB, nGN).

\section{Processing for TEM}

The frozen samples of tumour tissue, fixed in 3\% glutaraldehyde, were rinsed in $0,1 \mathrm{M}$ cacodylate buffer ( $\mathrm{pH} \sim 7.4$ ) and post-fixed in $1 \%$ osmium tetroxide. They were dehydrated in graded alcohols and propylene oxide and then embedded in epoxy resins, EPON 812. Subsequently, the samples were cut into semi-thin (100 $\mathrm{nm})$ and ultra-thin $(40-60 \mathrm{~nm})$ sections, by an ultra microtome. The latter were then contrasted with lead citrate and uranyl acetate, after their placement on copper grids. The finished ultra-thin samples were examined with a Transmission Electron Microscope (TEM, Morgagni 268D).

\section{Ultrastructural morphometry}

Ultrastructural morphometry was performed on TEM ultra-thin sections in 60 cells per sample of tumour

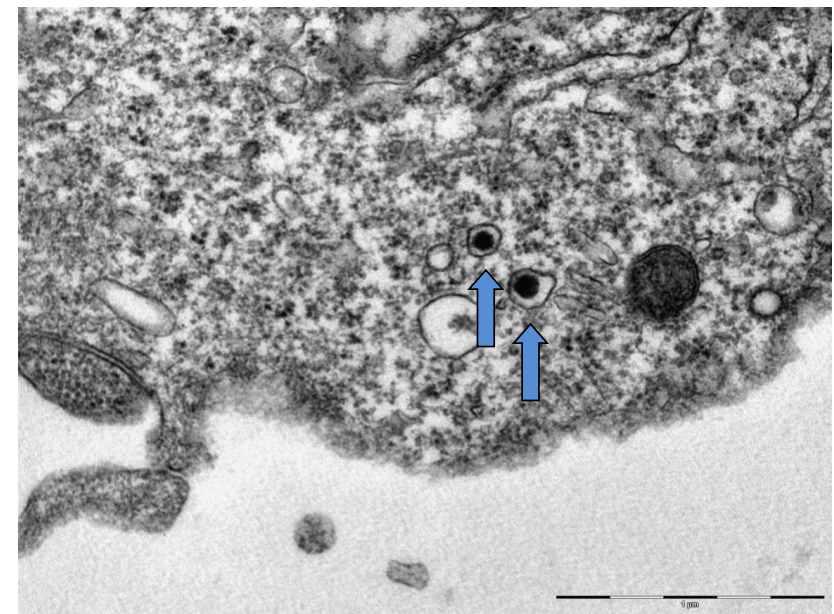

Picture 1. Electron photomicrograph of a favorable prognosis tumour cell (magnification $2800 \mathrm{x}$ ). A total of two NSGs visible (arrows) in cytoplasm of cellular process, on the periphery.

Morphometric analysis of neurosecretory granules in tumour cells

Using morphometric analysis, a regularity concerning the number of NSGs per sample and the tumour's prognosis has been discovered to be a larger number of NSGs present in the cytoplasm of cells of tumours with an unfavorable prognosis ( $141.2 \pm 89.18$ per 60 cells per sample, on average) than the corresponding number in tumours with a favorable prognosis $(37.2 \pm 41.17$ per 60 cells per sample, on average) (Table 1, Graph 1, Pictures 3 and 4). tissue. The structural hallmarks of the cells were observed and the number of NSGs in them counted. The analysis was done at a magnification that allowed maximum certainty whilst identifying the granules $(28000 \mathrm{x}-56000 \mathrm{x})$.

Statistical analysis

The acquired data was analyzed using Student's $\mathrm{t}$-test and significance was assumed for $\mathrm{p}<0.05$.

\section{Results}

Ultrastructural characteristics of neurosecretory granules

The neurosecretory granules were distinguished from the rest of the cytosol in photomicrographs as round structures with an electron dense centre, surrounded with an electron lucent, peripheral halo (Picture 1). In numerous tumour cells, NSGs were found in close proximity to the nucleus (Picture 2).

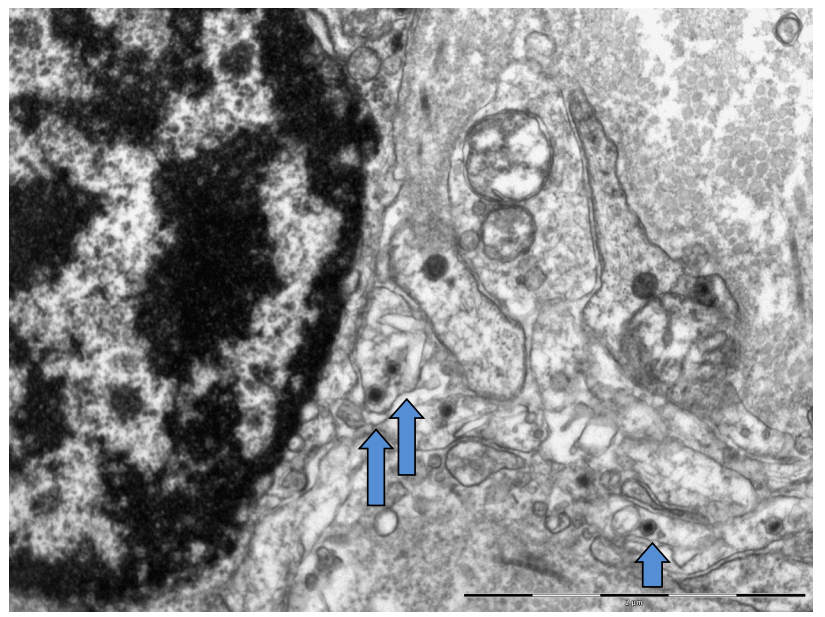

Picture 2. Electron photomicrograph of an unfavorable prognosis tumour cell (magnification $1800 x$ ). Numerous NSGs visible (arrows) in cytoplasm, in close proximity to nucleus.

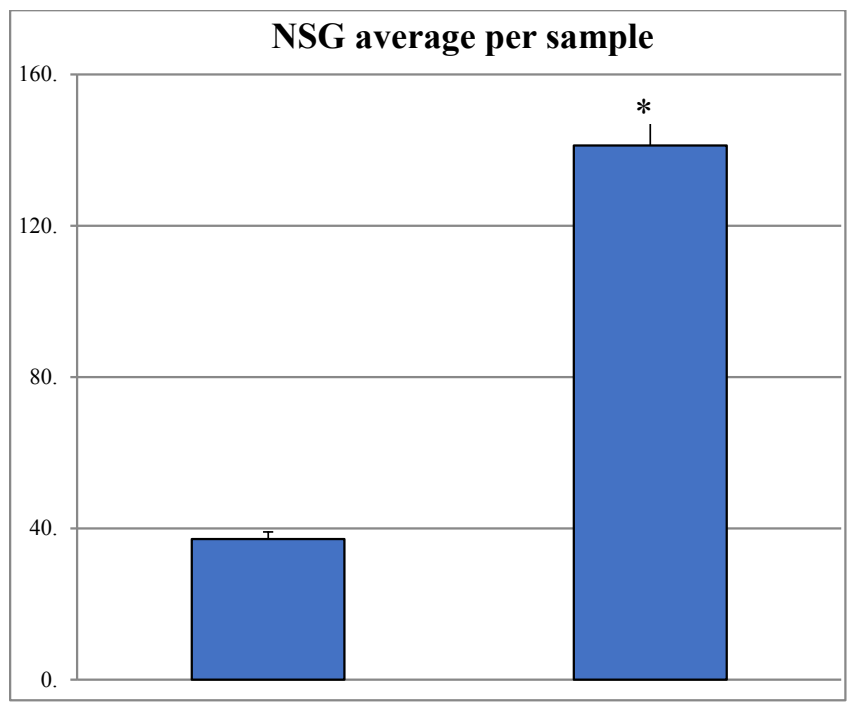

Tumours with a favorable prognosis Tumours with an unfavorable prognosis

Graph 1. An average number of NSGs per tumour sample with a favorable versus corresponding average in sample with an unfavorable prognosis (asterisk shows statistical significance at $\mathrm{p}$ $<0.05)$. 
Jovanović S. et al. Ultrastructural morphometry of neurosecretory granules in the neuroblastomas of paediatric patients. MedPodml 2018, 69(1):60-64

Table 1. The number of NSGs in tumours with a favorable and unfavorable prognosis.

\begin{tabular}{|lll|}
\hline $\begin{array}{l}\text { Sample } \\
\text { number }\end{array}$ & $\begin{array}{l}\text { FH tumours } \\
\text { (NSG count) }\end{array}$ & $\begin{array}{l}\text { UH tumours } \\
\text { (NSG count) }\end{array}$ \\
\hline 1. & 98 & 134 \\
2. & 0 & 290 \\
3. & 2 & 103 \\
4. & 29 & 52 \\
5. & 57 & 127 \\
\hline
\end{tabular}

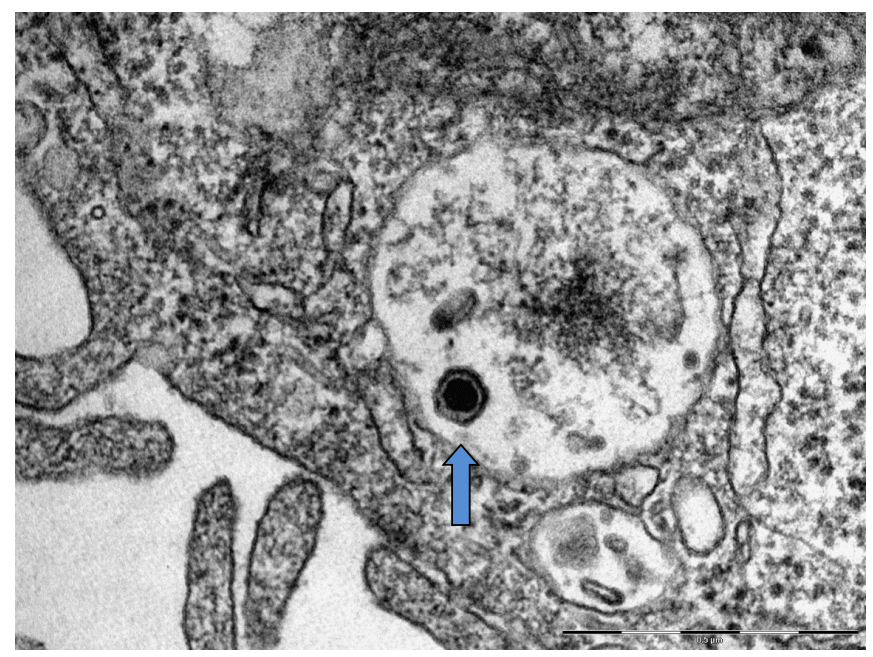

Picture 3. Electron photomicrograph of cell of ganglioneuroma (magnification $56000 x$ ). Photomicrograph shows one NSG visible (arrow) in cytoplasm, encased by autolysosome, with an electron dense core and electron lucent halo, as previously described.

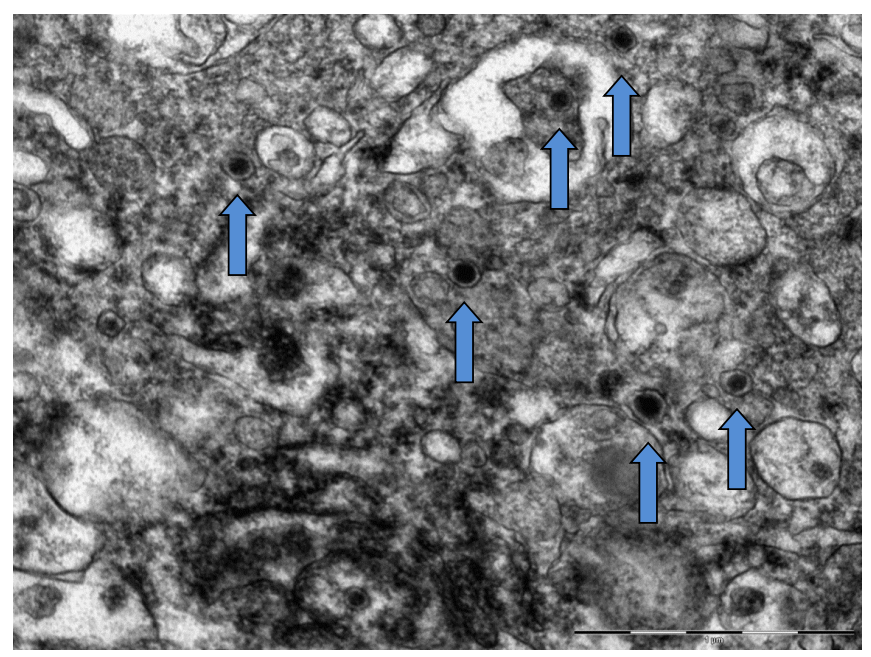

Picture 4. Electron photomicrograph of an unfavorable prognosis tumour cell (magnification 2 800x). Numerous NSGs visible in cytoplasm, some of which are marked (arrows).

\section{Discussion}

Peripheral neuroblastic tumours display a correlation between their morphological characteristics and prognoses, which could imply that systematic investigation of these differences between tumour cells, with varying outcomes and levels of differentiation, could prove to be useful in revealing the mechanisms of biological development of the said tumours (2).

The findings of our study have demonstrated ultrastructural differences between peripheral neuroblastic tumour cells of favorable and unfavorable prognosis, which have not been previously seen. We have found a significant increase in the number of NSGs in peripheral neuroblastic tumors with an unfavorable prognosis.

Neurosecretory granules, as structures that were the focus of this study, are approximately $100 \mathrm{~nm}$ in diameter $(7,10)$. Because of their small size, for the analysis of their presence and sum total in peripheral neuroblastic tumour cells, an electron microscopy analysis was performed.

Present ultrastructural findings support previous findings that cells in tumours with an unfavorable prognosis appear less differentiated (2). Our finding of the NSGs in cell bodies could, therefore, imply that NSGs have not yet extended from cell bodies into cell processes.

The increase in the number of NSGs in tumours with an unfavorable prognosis, could be explained either by an increase in the rate of their biogenesis or a disorder that effects the regulatory mechanisms of autophagy in these cells (11). Disruption in autophagy, the catabolic process in which a cell digests and eliminates its own macromolecules and organelles, could link the relatively larger number of NSGs to a poor prognosis (12).

The data compiled in this study suggests that the ultrastructural evaluation of the cells of peripheral neuroblastic tumours, more specifically the quantification of the neurosecretory granules contained therein, could be of significance in further explaining their tumourigenesis.

\section{Conclusion}

An increase in the number of neurosecretory granules in cells of tumours with an unfavorable prognosis, as established in this research, could partially shed light on the role these structures play in tumourigenesis. 
Jovanović S. et al. Ultrastructural morphometry of neurosecretory granules in the neuroblastomas of paediatric patients. MedPodml

\section{References}

1. Luksch R, Castellani MR, Collini P, De Bernardi B, Conte M, Gambini C, Gandola L, GaraventaA, Biasoni D, Podda M, Sementa AR, Gatta G, Tonini GP. Neuroblastoma (Peripheral neuroblastic tumours). Critical Reviews in Oncology/Hematology. 2016;107:163-181.

2. Mohlin AS, Wingerup C, Påhlman S. Neuroblastoma aggressiveness in relation to sympathetic neuronal differentiation stage. Seminars in Cancer Biology. 2011; 21:276-282.

3. Parham D. Neuroectodermal and Neuroendocrine Tumours Principally Seen in Children.American Journal of Clinical Pathology.2001; 115:113-128.

4. Cohn SL, Pearson AD, London WB, Monclair T, Ambros PF, Brodeur GM, Faldum A, Hero B,Iehara T, Machin D, Mosseri V, Simon T, Garaventa A, Castel V, Matthay KK; INRG Task Force.The International Neuroblastoma Risk Group (INRG) classification system: an INRG Task Force report. Journal of Clinical Oncology.2009; 27:289-297.

5. Nakazawa A, Haga C, Ohira M, Okita H, Kamijo T, Nakagawara A. Correlation between the International Neuroblastoma Pathology Classification and genomic signature in neuroblastoma.Cancer Science.2015; 106:766-771.

6. RomanskyS, Crocker D, Shaw K. Ultrastructural Studies on Neuroblastoma (EvaluationOf Cytodifferentiation and Correlation of Morphology and Biochemical and SurvivalData). Cancer. 1978; 2916:2392-2398.

7. Latimer E, Anderson G, Sebire NJ. Ultrastructural features of neuroblastic tumours in relation to morphological, and molecular findings; a retrospective review study. BMC Clinical Pathology. 2014; 14:13.

8. Scalettar AB. How neurosecretory vesicles release their cargo. Neuroscientist. 2006; 12:164-176.

9. Gutiérrez LM, Villanueva J. The role of F-actin in the transport and secretion of chromaffin granules: an historic perspective. Pflugers Archive: the European Journal of Physiology. 2018; 470:181-186.

10. Morris JF, Cannata MA. Ultrastructural preservation of the dense core of posterior pituitary neurosecretory granules and its implications for hormone release. Journal of Endocrinology.1973; 57:517-529

11. Samardzija G, Kravić-Stevović T, Đuričić S, Đokić $\mathrm{D}$, Đurišić $\mathrm{M}$, Ćirić $\mathrm{D}$, Martinović T, Bumbaširević V, Vujić D. Aggressive human neuroblastomas show a massive increase in the numbers of autophagic vacuoles and damaged mitochondria. Ultrastructural Pathology. 2016; 40:240-248.

12. Klionsky D et al. Guidelines for the use and interpretation of assays for monitoring autophagy (3rd edition). Autophagy. 2016; 12:1-222. 